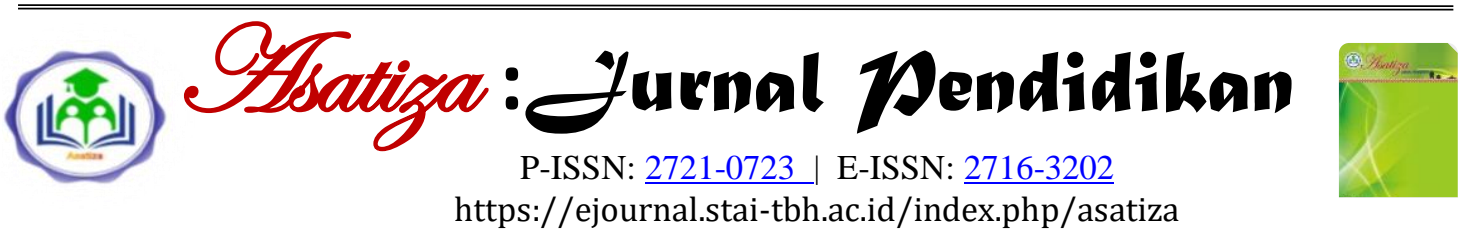

\section{Problematika Penggunaan Gadget dalam Pembelajaran Masa Pandemi Covid-19 (Dampak dan Solusi bagi Kesehatan Siswa)}

\author{
"Hamdan Adib ${ }^{1, a}$ \\ ${ }^{1}$ UIN Prof KH Saifuddin Zuhri, Purwokerto, Jawa Tengah, Indonesia \\ a adib.hamdan123@gmail.com
}

\begin{tabular}{l} 
INFORMASI \\
ARTIKEL \\
\hline Histori Artikel: \\
Diterima : 20/08/2021 \\
Direvisi : 22/09/2021 \\
Disetujui : 25/09/2021 \\
Diterbitkan : 30/09/2021 \\
\hline Keywords: \\
Gadget, Covid-19, \\
Learning, Student's \\
Health \\
Kata Kunci: \\
Gadget, Covid-19, \\
Pembelajaran, \\
Kesehatan Siswa \\
\hline DOI: \\
https://doi.org/10.46963/ \\
asatiza.v2i3.391 \\
\hline *Correspondence \\
Author: \\
adib.hamdan123@ @mail. \\
com
\end{tabular}

\begin{abstract}
The purpose of this study was to determine the effect of learning innovation during the Covid-19 pandemic and its relation to students' physical and mental health. The method used was a qualitative method using library research. The study showed that during the Covid-19 Pandemic, the teachers and students conducted their teaching and learning using media such as laptops, smartphones, or tablets connected through the network by providers or WiFi. Students' physical health was distracted due to the duration of using those media was too long. At the same time, insufficient supervision by parents also affected their psychological health since all information spread very quickly without any qualified filter. However, teachers also experienced the same cases as students' have. This study suggests that parents should take action not only to monitor the duration of their children's learning but also the content they access.
\end{abstract}

\begin{abstract}
Abstrak
Tujuan dari penelitian ini adalah untuk mengetahui pengaruh inovasi pembelajaran pada masa pandemi Covid-19 dan kaitannya dengan kesehatan fisik dan mental siswa. Metode yang digunakan adalah metode kualitatif dengan menggunakan studi kepustakaan. Hasil penelitian menunjukkan bahwa selama Pandemi Covid-19, para guru dan siswa melakukan belajar mengajar menggunakan media seperti laptop, smartphone, atau tablet yang terhubung melalui jaringan oleh provider atau WiFi. Kesehatan fisik siswa terganggu karena durasi penggunaan media tersebut terlalu lama. Pada saat yang sama, pengawasan yang tidak memadai oleh orang tua juga mempengaruhi kesehatan psikologis siswa karena semua informasi menyebar dengan sangat cepat tanpa filter yang berkualitas. Namun, guru juga mengalami kasus yang sama seperti yang dialami siswa. Studi ini menyarankan bahwa orang tua harus mengambil tindakan tidak hanya untuk memantau durasi belajar anak-anak mereka tetapi juga konten yang mereka akses.
\end{abstract}

Cara mensitasi artikel:

Adib, H. (2021). Problematika penggunaan gadget dalam pembelajaran masa pandemi covid-19 (Dampak dan solusi bagi kesehatan siswa). Asatiza: Jurnal Pendidikan, 2(3), 170-179. https://doi.org/10.46963/asatiza.v2i3.391

\section{PENDAHULUAN}

Pandemi memberikan dampak yang sangat luas bagi kehidupan manusia, baik sosial budaya agama dan juga Pendidikan. Guru sekolah di berikan kesempatan dalam mengembangkan media pembelajaran sebagai sarana dalam inovasi dan keberlangsungan pembelajaran, salah satu inovasi tersebut adalah pelaksanaan pembelajaran daring. 
pelaksanaan pembelajaran daring adalah pelaksanaan pembelajaran yang dilakukan dari jauh atau tidak secara tatap muka, namun hal ini memberikan keniscayaan terpenuhinya sarana dan prasarana yang mendukung diantaranya adalah media elektronik berupa tablet atau smartphone. Selain itu harus terpenuhi juga jaringan yang dapat digunakan dalam mengakses internet, bisa berupa kuota dari provider yang sudah ada atau dengan menggunakan jaringan WiFi. Jadi bisa dikatakan bahwa pembelajaran model daring membutuhkan biaya yang tidak sedikit.

Penggunaan tablet atau smartphone memberikan kemudahan dalam akses pembelajaran, siswa tinggal memilih dan mengolah segala media informasi yang disediakan sehingga tinggal dalam genggaman saja semua informasi yang dibutuhkan, tampilan yang inovatif memberikan daya tarik tersendiri bagi penggunaannya terlebih lagi bagi siswa yang masih ingin terus mencari segala informasi hal ini berkaitan dengan tingkat usia siswa di mana masih dalam usia pencarian jati diri.

Namun dibalik itu semua ada dampak negatif yang mengintai kesehatan baik fisik maupun psikis bagi siswa, hal ini berkaitan dengan durasi penggunaan smartphone yang begitu lama karena siswa asyik dalam memainkannya. Ternyata perlombaan guru dalam membuat konten yang menarik bagi siswa yang ditujukan agar siswa menarik dalam mempelajari materi yang diberikan guru belum mampu mengatur waktu yang baik dalam menggunakan smartphone bagi siswa. guru seringnya hanya membuat materi namun tidak melihat efek jika siswa terlalu lama menggunakan smartphone.

Selain itu aplikasi yang di tawarkan di dalam smartphone juga jauh lebih menarik, terlebih lagi ketika sekolah hanya melakukan pembelajaran via daring, sebenarnya orang tualah yang harus memberikan rem kepada peserta didik dalam penggunaan smartphone namun tanpa disadari ketergantungan orang tua terhadap sekolah sangat tinggi sehingga sampai pembelajaran daring pun orang tua masih menggantungkan semuanya kepada sekolah dan dengan harapan yang tinggi segera dilaksanakan tatap muka.

Selain bagi siswa, hal serupa juga berpengaruh kepada guru. Karena guru tidak bisa lepas dari perangkat keras yang digunakan dalam membuat materi, menyusun materi, evaluasi materi, penilaian siswa, pelaporan siswa. ternyata risiko kesehatan guru jauh lebih tinggi sehingga hal ini akan mengakibatkan menurunnya kesehatan guru baik dalam kesehatan jasmani dan psikis.

Penelitian yang dilakukan oleh Erni Pujiasih (Pujiasih, 2020) menyatakan bahwa inovasi pembelajaran dibutuhkan untuk mempersiapkan generasi emas tahun 2045 dengan memberikan berbagai variasi pembelajaran, variasi ini didalamnya memanfaatkan pembelajaran online di mana terdapat kelemahan dan kelebihannya, kelemahan yang diberikan baik secara teknis ataupun ketidaksiapan siswa. Namun dalam penelitian ini tidak dijelaskan dampak dari terlalu intensnya siswa di jenjang sekolah dasar dan menengah dalam menggunakan smartphone sehingga ini menjadi titik perbedaan penelitian ini dengan yang 
dilakukan oleh peneliti. Melalui permasalahan kesehatan bagi siswa jenjang pendidikan dasar dan menengah serta guru inilah penulis merasa tertarik dalam melihat sejauh mana dampak dari penggunaan gadget bagi guru dan siswa kaitannya dengan pembelajaran daring.

\section{METODE}

Penelitian kali ini menggunakan studi Kepustakaan. Abdul Rahman Sholeh menjelaskan bahwa penelitian kepustakaan adalah penelitian yang menggunakan cara untuk mendapatkan data informasi dengan menempatkan fasilitas yang ada di perpustakaan, seperti buku, majalah, dokumen dan catatan kisah-kisah sejarah (Sunarsa, 2020).

Tahap penelitian pustaka yaitu 1) menyiapkan alat perlengkapan yang diperlukan, 2) menyiapkan bibliografi kerja (working biblioghraphy), 3) mengorganisasikan waktu dan 4) kegiatan membaca dan mencatat bahan penelitian (Zed, 2014).

Peneliti akan melakukan pengumpulan data mengenai informasi yang berkaitan dengan dampak penggunaan gadget khususnya bagi anak pada jenjang pendidikan dasar dan menengah. Rujukan utama kaitannya dengan menganalisis problematika ini yaitu buku Iswidharmanjaya, D., \& Agency, B. Dengan judul "Bila Si Kecil Bermain Gadget: Panduan bagi orang tua untuk memahami faktor-faktor penyebab anak kecanduan gadget". Kemudian literatur lainnya yang mendukung berupa berita, kebijakan, kajian literatur berupa buku, jurnal dan lain sebagainya yang mendukung ketersediaan data di dalam penelitian untuk selanjutnya dilakukan analisis.

\section{HASIL DAN PEMBAHASAN Inovasi Pendidikan masa pandemi}

Melihat keadaan sekarang ini masih dalam masa pandemi, maka guru tidak bisa melakukan proses pembelajaran seperti biasanya, maka dari itu dibutuhkan inovasi yang dapat merubah pola pembelajaran dari yang biasanya yaitu tatap muka menjadi pembelajaran yang dilakukan tanpa melakukan tatap muka atau dengan kata lain adalah pembelajaran jarak jauh. Zhafira menjelaskan bahwa ada guru sebenarnya dapat menggunakan beberapa model pembelajaran yang dapat membantu guru dalam menyampaikan materi pelajaran yaitu pembelajaran daring (dalam jaringan) dan pembelajaran campuran (gabungan antar dua model pembelajaran yaitu tatap muka dan pembelajaran daring) (Zhafira, Ertika, \& Chairiyaton, 2020). Pembelajaran dengan menggunakan model daring tidak mengharuskan siswa ada di kelas. Siswa dapat melakukan proses pembelajaran melalui media internet. hal ini sesuai dengan yang dijelaskan oleh albert efendi pohan yang menyatakan bahwa pembelajaran daring juga dikatakan sebagai pembelajaran jarak jauh (learning distance) di mana dalam pelaksanaan pengajaran guru dan siswa tidak melakukan tatap muka secara langsung (Albert Efendi Pohan, 2020). Sebenarnya pembelajaran daring ini bukan lagi model pembelajaran yang baru yang tercipta karena adanya pandemi saat ini. Pembelajaran daring sendiri digunakan pada saat ini karena dianggap pembelajaran paling efektif dengan 
keadaan di mana pada saat ini setiap orang wajib menjaga jarak, dan larangan berkerumun demi menghindari tertularnya Covid-19. Pelaksanaan pembelajaran daring bukan merupakan hal yang tidak berdasar, karena pembelajaran ini sesuai dengan surat edaran menteri pendidikan No. 3 tahun 2020 pada satuan pendidikan dan No. 36962/MPK.A/HK/2020 mengenai pelaksanaan pendidikan dalam masa darurat Covid-19 dengan melaksanakan kegiatan pembelajaran secara daring yang ditujukan untuk mencegah menyebarnya Covid-19 (Dewi, 2020). Mengingat pelaksanaan pembelajaran daring menggunakan media yang awalnya tidak biasa digunakan baik oleh guru ataupun siswa, maka para guru harus selalu mempelajari dan meningkatkan pemahamannya mengenai media yang digunakan demi keefektifan proses belajar mengajar tidak terkecuali yang digunakan dalam pembelajaran daring ini (Salsabila, Seviarica, \& Hikmah, 2020).

Sebenarnya pembelajaran online tidak hanya berguna pada saat pandemi saja, namun dalam pembelajaran yang dilakukan di dalam kelas (classroom instruction) juga berguna, yaitu sebagai: 1) Suplemen bagi siswa, dalam hal ini model pembelajaran hanya dijadikan sebagai suplemen di mana sifatnya tidak wajib, siswa dapat mengambil dan melaksanakan pembelajaran online jika siswa menginginkan namun jika tidak dimanfaatkan tidak berakibat buruk bagi perkembangan pembelajaran siswa. 2) Komplemen, pembelajaran online dalam hal ini bersifat pelengkap, jadi pelengkap dari pembelajaran yang disediakan melalui pembelajaran tatap muka. Biasanya materi yang ada dalam pembelajaran online digunakan dalam pengayaan atau remedial bagi siswa yang tidak memenuhi target capaian yang ditentukan dalam mengikuti kegiatan pembelajaran konvensional. 3) Substitusi, sebagai substitusi jika materi pembelajaran online diprogramkan untuk menggantikan materi pembelajaran yang diterima siswa di kelas (Waryanto, 2006). Pembelajaran online juga memiliki nama lain e-learning. Menurut Hanum pembelajaran online atau e-learning merupakan suatu model pembelajaran yang dalam pelaksanaannya membutuhkan teknologi informasi dan komunikasi sehingga tanpa adanya dua hal itu pembelajaran tidak akan dapat dilakukan (Hanum, 2013).

Sebenarnya definisi elearning sangat banyak sekali diantaranya, didefinisikan dengan bentuk dunia maya yang menjadi inovasi dalam bidang Pendidikan yang dalam mengaksesnya membutuhkan teknologi informasi. Munir mengatakan bahwa istilah e-learning lebih tepat digunakan untuk peralihan model pembelajaran ke arah digitalisasi dengan memanfaatkan jaringan internet baik di sekolah maupun di perguruan tinggi. Sedangkan Seok memberikan pernyataan bahwa "e-learning is a new form of pedagogy for learning in the $21^{\text {th }}$ century. E-teacher are e-learning instructional designer, facilitator of interaction, and subject matter experts". E-learning didefinisikan sebagai sistem pembelajaran yang open source, sistem pembelajaran di mana dalam mengaksesnya menggunakan aplikasi web yang dapat dijalankan dan 
diakses dengan web browser (Noveandini \& Wulandari, 2010).

E-learning adalah sistem pendidikan yang menggunakan aplikasi elektronik untuk mendukung belajar mengajar dengan media jaringan komputer lain (Noveandini \& Wulandari, 2010). Warkintin dan Mulyadi, mendefinisikan yaitu suatu sistem yang mengembangkan misi cukup luas yang berhubungan dengan perkembangan fisik, keterampilan, pikiran, perasaan, kemampuan, sosial sampai kepada masalah kepercayaan atau keimanan. Sehingga apa pun hambatan ataupun rintangan pendidikan tetap berjalan dengan baik (Warkintin \& Mulyadi, 2019).

Hambatan dalam hal ini adalah hambatan yang dialami guru yaitu proses pembelajaran yang dilakukan secara jarak jauh atau daring dan menafikan pembelajaran tatap muka yang dilakukan di kelas karena dalam masa pandemi. Kondisi tersebut menuntut guru untuk melakukan inovasi dalam proses pembelajaran khususnya pembelajaran melalui daring (dalam jaringan). Solusi yang dilakukan selama masa pandemi adalah mencari solusi dengan menggunakan pembelajaran berbasis dalam jaringan. Guru dituntut untuk inovatif dalam menggunakan pembelajaran dengan model daring. Hal ini sejalan dengan pendapat dari Tjandra, D. S., bahwa guru hanya memfasilitasi dengan perpustakaan kelas, modul, buku teks, serta buku-buku pendukung, dan yang terpenting akses internet, serta menyediakan beberapa komputer untuk para siswa yang tidak membawa laptop.
Bentuk e-learning (pembelajaran berbasis elektronik) akan tetap ada dan terus berkembang (Tjandra, 2020).

Seiring dengan kepemilikan komputer yang tumbuh pesat di dunia, $e$ learning menjadi semakin berkembang dan mudah diakses. Kecepatan koneksi internet semakin meningkat, dan dengan itu, peluang metode pelatihan multimedia yang lebih banyak bermunculan. Harapan dalam pembelajaran dengan model daring adalah menjadi sebuah solusi yang dapat membantu pembelajaran di tengah pandemi Covid-19 (Anugrahana, 2020).

\section{Dampak penggunaan gadget pada anak}

Dampak yang didapatkan dalam menggunakan gadget yaitu: Pertama, radiasi yang ditimbulkan dari smartphone sangat berbahaya bagi daya kembang khususnya anak, di mana Radiasi elektromagnetik terdiri dari gelombang elektrik dan energi magnetik dengan kecepatan cahaya. Semua energi elektromagnetik jatuh pada spektrum elektromagnetik. Frekuensi yang mampu di pancarkan oleh gadget seperti telepon genggam yakni berada di kisaran 800$2540 \mathrm{MHz}$ yaitu termasuk gelombang radio (radiasi ELF). Walaupun tak sekuat sinar $\mathrm{X}$ yang merupakan jenis radiasi terionisasi dan mampu mengubah material genetik, perlu diketahui bahwa radiasi yang terpancar di dalam smartphone sangat berpengaruh kepada tubuh manusia. Bahaya radiasi gadget terhadap daya kembang anak adalah radiasi dari penggunaan gadget yang tergolong gelombang RF, jika diamati lebih jauh gelombang ini bukan merupakan gelombang yang memiliki tingkat bahaya yang sampai menyebabkan pada kematian, 
namun hal ini tidak bisa dianggap aman karena gelombang ini tetap akan memberikan efek samping. Radiasi RF pada level tinggi serta dengan intensitas yang intensif dapat merusak jaringan tubuh. Radiasi RF memiliki kemampuan untuk memanaskan jaringan tubuh seperti oven microwave memanaskan makanan. Dan radiasi tersebut dapat merusak jaringan tubuh, karena tubuh kita tidak dilengkapi sistem ketahanan untuk mengantisipasi sejumlah panas berlebih akibat radiasi RF. Penelitian lain menunjukkan radiasi non-ionisasi (termasuk gelombang RF) menimbulkan efek jangka panjang.

Banyak penyakit yang berpotensi muncul yang disebabkan oleh radiasi dalam menggunakan smartphone beberapa penyakit itu adalah kanker, tumor otak, alzheimer, parkinson, sakit kepala. Dibanding orang dewasa, anakanak zaman sekarang sudah mengenal teknologi nirkabel sejak kecil sehingga waktu „bersentuhan" dengan radiasi lebih panjang. Hal ini disebabkan karena di usia 12-15 tahun, anak mengalami proses bangkitnya akal, nalar dan kesadaran diri. Dalam masa ini terdapat energi dan kekuatan fisik serta tumbuh keinginan tahu dan keinginan coba-coba. Melalui data yang sudah ada dapat dipahami bahwa ketika radiasi yang ditimbulkan melalui smartphone mulai memasuki kepala, maka perhitungan jumlahnya adalah anak yang memiliki usia 5 tahun sebanyak $75 \%$, anak-anak yang memiliki usia 12 tahun menyerap 50\% dan orang dewasa dapat menyerap sebanyak $25 \%$. Melalui data ini dapat disimpulkan bahwa penyerapan radiasi yang paling tinggi adalah bagi anak-anak, sehingga bagi anak di bawah usia 16 tahun, namun sudah memiliki kecanduan terhadap smartphone, maka risiko terpapar radiasi akan sangat tinggi (Sugianto, Prayanto, \& Yudani, 2015).

Kedua, Pengaruh Gadget terhadap Perkembangan Anak, Pengaruh penggunaan gadget terhadap perkembangan anak memiliki dampak positif dan dampak negatif. Adapun dampak positifnya antara lain, membantu perkembangan fungsi adaptif seorang anak, menambah pengetahuan anak, memperluas jaringan persahabatan, mempermudah komunikasi, dan membangun kreativitas anak. Sedangkan dampak negatifnya antara lain, anak menjadi ketergantungan terhadap gadget, sehingga dalam menjalankan segala aktivitas hidupnya anak tidak bisa terlepas dari gadget, anak menjadi sulit berkonsentrasi pada dunia nyata, anak menjadi lebih suka bermain dengan gadgetnya daripada bermain dengan temannya, dan anak menjadi malas bergerak dan beraktivitas. Selain itu, dampak positif penggunaan gadget antara lain, yang pertama adalah gadget akan membantu perkembangan fungsi adaptif seorang anak artinya kemampuan seseorang untuk bisa menyesuaikan diri dengan keadaan lingkungan sekitar dan perkembangan zaman. Jika perkembangan zaman sekarang muncul gadget, maka anak pun harus tahu cara menggunakannya karena salah satu fungsi adaptif manusia zaman sekarang adalah harus mampu mengikuti perkembangan teknologi. Sebaliknya, anak yang tidak bisa mengikuti perkembangan teknologi 
bisa dikatakan fungsi adaptifnya tidak berkembang secara normal. Nilai positif lain adalah gadget memberi kesempatan anak untuk leluasa mencari informasi. Apalagi anak-anak sekolah sekarang dituntut untuk mengerjakan tugas melalui internet (Nazir, 2003).

Penggunaan gadget yang berlebihan pada anak akan berdampak negatif karena dapat menurunkan daya konsentrasi dan meningkatkan ketergantungan anak untuk dapat mengerjakan berbagai hal yang semestinya dapat mereka lakukan sendiri. Dampak lainnya adalah semakin terbukanya akses internet dalam gadget yang menampilkan segala hal yang semestinya belum waktunya dilihat oleh anak-anak. Banyak anak yang mulai kecanduan gadget dan lupa bersosialisasi dengan lingkungan sekitarnya yang berdampak psikologis terutama krisis percaya diri, juga pada perkembangan fisik anak. Radiasi gelombang elektromagnetik dari gadget memang tidak terlihat, efeknya pun tidak terasa secara langsung. Untuk itu orang tua harus secara bijak mengawasi dan melakukan seleksi terhadap instrumen permainan yang digunakan anak-anak saat bermain. Kebiasaan anak-anak dalam bermain gadget saat ini memang tidak bias dipungkiri, namun ada baiknya tidak selalu bermain, atau paling tidak membatasi waktu bermain gadget, karena alasan radiasi di atas. Sebenarnya kegiatan bermain merupakan kegiatan utama anak yang tampak mulai sejak bayi. Kegiatan ini penting bagi perkembangan kognitif, sosial, dan kepribadian anak pada umumnya. Anak juga bisa mulai memahami hubungan antara dirinya dan lingkungan sosialnya melalui kegiatan bermain, belajar bergaul dan memahami aturan ataupun tata cara pergaulan. Namun sekarang anak lebih banyak menghabiskan waktu dengan bermain gadget dari pada bermain dengan teman sebaya, yang bisa menimbulkan sifat individualis dan egosentris, serta tidak memiliki kepekaan terhadap lingkungan sekitar (Sugianto et al., 2015).

Ketiga, Beberapa dampak negatif dari gadget untuk perkembangan anak (Nazir, 2003), 1) Sulit konsentrasi pada dunia nyata, Rasa kecanduan atau adiksi pada gadget akan membuat anak mudah bosan, gelisah dan marah ketika dia dipisahkan dengan gadget kesukaannya. Ketika anak merasa nyaman bermain dengan gadget kesukaannya, dia akan lebih asyik dan senang menyendiri memainkan gadget tersebut. Akibatnya, anak akan mengalami kesulitan berinteraksi dengan dunia nyata, berteman dan bermain dengan teman sebaya. 2) Terganggunya fungsi PFC (Pre-Frontal Cortex). Kecanduan teknologi selanjutnya dapat mempengaruhi perkembangan otak anak. PFC atau Pre-Frontal Cortex adalah bagian di dalam otak yang mengontrol emosi, kontrol diri, tanggung jawab, pengambilan keputusan dan nilai-nilai moral lainnya. Anak yang kecanduan teknologi seperti games online, otaknya akan memproduksi hormon dopamine secara berlebihan yang mengakibatkan fungsi PFC terganggu. 3) Introvert, Ketergantungan terhadap gadget pada anak-anak membuat mereka menganggap bahwa gadget itu adalah segala-galanya bagi mereka. Mereka akan galau dan gelisah jika dipisahkan dengan gadget 
tersebut. Sebagian besar waktu mereka habis untuk bermain dengan gadget. Akibatnya, tidak hanya kurangnya kedekatan antara orang tua dan anak, anak juga cenderung menjadi introvert. Selain daripada keterangan di atas, berikut di bawah ini merupakan dampak buruk penggunaan gadget pada anak antara lain: Menjadi pribadi tertutup, Kesehatan otak terganggu, Kesehatan mata terganggu, Kesehatan tangan terganggu, Gangguan tidur, Suka menyendiri, Perilaku kekerasan, Pudarnya kreativitas, Terpapar radiasi, Ancaman cyber bullying (Iswidharmanjaya \& Agency, 2014).

Gangguan psikologis lainnya yang dialami siswa jika sudah mengalami ketergantungan kepada gadget yaitu adanya kecemasan sosial. Penelitian yang dilakukan oleh Fatih Azka menjelaskan bahwa terdapat pengaruh kecemasan sosial dengan ketergantungan pada media sosial. Hal ini menjelaskan bahwa orang yang sudah tergantung akan satu hal baik itu media sosial ataupun gadget akan memiliki kecemasan sosial di mana individu akan sangat cemas ketika harus berinteraksi dan bersosialisasi secara langsung dengan orang lain. Hal ini mengakibatkan individu akan bergantung pada media komunikasi yang hanya dilaksanakan pada dunia maya (Azka, 2018).

Solusi dalam Penggunaan gadget

Penggunaan gadget dalam pelaksanaan pembelajaran daring memang suatu keuntungan tersendiri bagi siswa dan orang tua, selain tidak membutuhkan tatap muka bagi guru dan siswa, siswa juga diajak untuk berpikir kreatif dalam mengembangkan materi pelajaran yang disediakan dari sekolah. Terlepas dari itu semua hal ini membutuhkan kerja sama antar guru dan orang tua dalam mengawasi aktivitas siswa.

Pengetahuan dan wawasan maupun keterampilan bagi orang tua maupun guru dan pengasuh anak mengenai penggunaan gadget yang bijak sangatlah penting. Mengingat saat ini masih banyak orang tua yang abai karena kesibukannya, membiarkan anak bermain gadget dengan waktu dan konten yang tidak dibatasi. Akibatnya, kondisi ini sangat rentan membuat anak dan remaja menjadi kecanduan gadget, atau bahkan menjadi korban dari pemangsa anak (predator anak) yang kini kerap beroperasi melalui gadget. oleh karena itu diperlukan edukasi yang tepat untuk memahami penggunaan gadget dengan baik dan benar, terutama agar tidak lagi ada orang-orang yang kecanduan gadget yang dapat memicu dampak negatif lainya secara fisik maupun psikis seseorang, apalagi hal tersebut menimpa orang sejak sangat dini. Yaitu usia anak dan remaja (Subagijo, 2020).

Selain pengawasan terhadap konten dan segala hal yang diakses siswa, orang tua juga perlu mengawasi jam penggunaan gadget. Batasi penggunaan smartphone dengan tidak lebih dari 30 menit per satu kali bermain, jeda sebentar dengan berjalan, bergerak, ke toilet, menggerakkan tubuh atau memandang ke arah jauh untuk relaksasi mata dan tubuh (Esther Setiawati \& Kids, 2016).

Selain pengawasan itu, orang tua juga harus bisa mengarahkan anaknya untuk mengatur waktu yang dimiliki. Manajemen waktu yang kurang baik menunjukkan bahwa siswa tidak memiliki 
kontrol diri yang baik dan berakibat pada menumpuknya tugas yang disebabkan penundaan waktu. Orang tua bisa melakukan kontrak waktu dengan anaknya di mana kontrak waktu ini merupakan perjanjian dalam menetapkan waktu untuk kegiatan belajar anak. Waktu ini ditujukan untuk melaksanakan aktivitas belajar sebagai pengganti tidak dilakukannya kegiatan sekolah. manajemen waktu yang baik menurut beberapa penelitian yang ter kodifikasi di dalam Ira Nurmala akan membantu siswa dalam melakukan problem solving, meningkatkan motivasi hidup, mampu mengaktualisasikan dirinya pada kegiatan positif, dan meningkatkan prestasinya, namun semua ini membutuhkan pemahaman yang tepat mengenai manajemen waktu (Nurmala, 2020).

\section{SIMPULAN}

Inovasi pembelajaran dengan menggunakan media daring merupakan hal yang sangat membantu, tidak hanya guru Islam saja, namun segala jenis pembelajaran dapat terbantu dengan adanya pembelajaran daring, namun siswa dan orang tua wajib mengetahui tentang waktu dan informasi yang diakses, sehingga ada pemantauan secara langsung oleh orang tua, orang tua tidak boleh hanya pasrah kepada anak mengenai penggunaan gadget sehingga seperti lepas kontrol yang akan membahayakan kehidupan siswa.

Selain itu durasi penggunaan yang baik juga harus dipahami oleh orang tua karena banyak bahaya yang mengintai dari segi kesehatan fisik siswa, yaitu berkaitan dengan kinerja mata khususnya. Hal ini juga perlu diperhatikan oleh siswa. inovasi pembelajaran masa daring tidak semuanya harus di buat menggunakan media elektronik khususnya laptop. Karena penggunaan laptop juga mengakibatkan menurunnya kinerja mata bagi guru.

\section{REFERENSI}

Albert Efendi Pohan, S. P. M. P. (2020). Konsep Pembelajaran Daring Berbasis Pendekatan Ilmiah. Penerbit CV. Sarnu Untung.

Anugrahana, A. (2020). Hambatan, solusi dan harapan: Pembelajaran daring selama masa pandemi covid-19 oleh guru Sekolah Dasar. Scholaria:

Jurnal Pendidikan Dan

Kebudayaan, 10(3), 282-289. https://doi.org/10.24246/j.js.2020.v1 0.i3.p282-289

Azka, F., Firdaus, D.F., Kurniadewi, E. (2018). Kecemasan sosial dan ketergantungan media sosial pada mahasiswa. Psympathic: Jurnal Ilmiah Psikologi, 5(2), 201-210. https://doi.org/10.15575/psy.v5i2.33 15

Dewi, W. A. F. (2020). Dampak Covid-19 terhadap implementasi pembelajaran daring di Sekolah Dasar. Edukatif: Jurnal Ilmu Pendidikan, 2(1), 55-61.

Esther Setiawati, M. P., \& Kids, H. H. (2016). Ayah Ibu Baik. Happy Holy Kids.

Hanum, N. S. (2013). Keefetifan elearning sebagai media pembelajaran (studi evaluasi model pembelajaran e-learning SMK Telkom Sandhy Putra Purwokerto). Jurnal Pendidikan Vokasi, 3(1), 90-102. https://doi.org/10.21831/jpv.v3i1.15 84

Iswidharmanjaya, D. (2014). Bila Si Kecil Bermain Gadget: Panduan bagi orang tua untuk memahami Factorfaktor Penyebab Anak Kecanduan Gadget, 1. Bisakimia.

Nazir, M. (2003). Metode penelitian. Ghalia Indonesia. 
Noveandini, R., \& Wulandari, M. S. (2010). Pemanfaatan media pembelajaran secara online (elearning) bagi wanita karir dalam upaya meningkatkan efektivitas dan fleksibilitas Pemantauan Kegiatan Belajar Anak Siswa/i Sekolah Dasar. Seminar Nasional Aplikasi Teknologi Informasi (SNATI).

Nurmala, I. (2020). Mewujudkan Remaja Sehat Fisik, Mental dan Sosial: (Model Intervensi Health Educator for Youth). Airlangga University Press.

Pujiasih, E. (2020). Building a golden generation by applying various online learning in the pandemic of covid-19. Ideguru: Jurnal Karya Ilmiah Guru, 5(1), 42-48. https://doi.org/10.51169/ideguru.v5i 1.136

Salsabila, U. H., Sofia, M, N., Seviarica, H. P., \& Hikmah, M. N. (2020). Urgensi penggunaan media audiovisual dalam meningkatkan motivasi pembelajaran daring di sekolah dasar. INSANIA: Jurnal Pemikiran Alternatif Kependidikan, 25(2), 284-304. https://doi.org/https://doi.org/10.240 90/insania.v25i2.4221

Subagijo, A. (2020). Diet dan Detoks Gadget. Noura Books.

Sugianto, V. J., Prayanto, W. H., \& Yudani, H. D. (2015). Perancangan board game mengenai bahaya radiasi gadget terhadap anak. Jurnal DKV Adiwarna, 1(6), 1-15.

Sunarsa, S. (2020). Penelusuran Kualitas dan Kuantitas Sanad Qira'at Sab': Kajian Takhrij Sanad Qira'at Sab'. Penerbit Mangku Bumi.

Tjandra, D. S. (2020). Impelementasi pembelajaran pendidikan agama Kristen di abad 21. SIKIP: Jurnal Pendidikan Agama Kristen, 1(1), 1-
10.

https://doi.org/10.52220/sikip.v1i1.3 3

Warkintin, W., \& Mulyadi, Y. (2019). Pengembangan bahan ajar berbasis CD interaktif power point untuk meningkatkan hasil belajar siswa. Scholaria: Jurnal Pendidikan Dan Kebudayaan, 9(1), 82-92. https://doi.org/10.24246/j.js.2019.v9. i1.p82-92

Waryanto, N. H. (2006). Online learning sebagai salah satu inovasi pembelajaran. Pythagoras, 2(1), 1023.

Zed, M. (2014). Metode Penelitian Kepustakaan. Yayasan Pustaka Obor Indonesia.

Zhafira, N. H., Ertika, Y., \& Chairiyaton, C. (2020). Persepsi mahasiswa terhadap perkuliahan daring sebagai sarana pembelajaran. Jurnal Bisnis dan Kajian Strategi Manajemen, 4(1), 37-45. https://doi.org/10.35308/jbkan.v4i1. 1981 